\title{
Replication and reinsertion of stalagmites sampled for paleoclimatic purposes
}

\author{
Eleuterio Baeza ${ }^{1 *}$, Rafael P. Lozano ${ }^{1}$, and Carlos Rossi ${ }^{2}$ \\ ${ }^{1}$ Museo Geominero-Instituto Geológico y Minero de España, Ríos Rosas 23, 28003 Madrid, Spain \\ ${ }^{2}$ Department Petrología y Geoquímica, Facultad de Ciencias Geológicas, Universidad Complutense, 28040 Madrid, Spain
}

\begin{abstract}
Sampling stalagmites for paleoclimatic study can enter into conflict with preserving the beauty and integrity of caves. To minimize this impact, a variety of sampling strategies have been used by researches aware of cave-conservation issues. Based on our experience in two caves (El Soplao and La Buenita, Cantabria, N Spain), we propose to apply molding and casting laboratory techniques to create replicas of stalagmites, placing the replicas back in the original cave locations so that the impact of sampling to the cave is severely reduced. We provide detailed descriptions of the molding and casting methods, which vary depending on stalagmite size. For relatively small specimens (less than $\sim 35 \mathrm{~cm}$ tall), we use a single-piece mold and two jackets. For larger stalagmites ( 40-70 cm tall), we use a two-piece mold and two jackets. In a first casting step, we obtain a master piece in dental plaster that is preserved. In a subsequent casting step, we use epoxy resin to generate the replica that will be placed in the cave. We use extra-hard plaster coated with epoxy resin to fix the replicas to their original substrates. Both the epoxy resin and plaster are carefully dyed to match the original surface texture and color of the sampled stalagmites. Once in place, the stalagmite replicas are almost indistinguishable from the natural specimens.
\end{abstract}

Keywords: $\quad$ speleothem sampling, stalagmite reinsertion, molding and casting, paleoclimatology, geoethics Received 24 January 2018; Revised 2 April 2018; Accepted 2 April 2018

Citation: $\quad$ Baeza E., Lozano R.P. and Rossi C., 2018. Replication and reinsertion of stalagmites sampled for paleoclimatic purposes. International Journal of Speleology, 47 (2), 137-144. Tampa, FL (USA) ISSN 0392-6672 https://doi.org/10.5038/1827-806X.47.2.2183

\section{INTRODUCTION}

Stalagmites can preserve valuable paleoclimate information with high temporal resolution compared to other proxy records (e.g., marine or lacustrine sediment cores), and provide important paleoclimate information for most continental regions (Fleitmann \& Spötl, 2008; Fairchild \& Baker, 2012). Also, stalagmites can be precisely dated using U-series methods. Therefore, stalagmites are increasingly being used for paleoclimate research, as there is a need to understand the climatic past in order to evaluate the magnitude, causes and consequences of the present day climate change.

The paleoclimatic study of a stalagmite normally requires its removal from the cave for petrographic and geochemical analysis, hence disturbing to some extent the integrity of the cave and potentially creating a conflict between scientific sampling and cave conservation (Springer, 2012; Truebe, 2013).

The paleoclimatic interpretation of stalagmite records is not straightforward, partly because they may be influenced by local factors that overlap with climatic controls. Therefore, some stalagmites may not be ideal for paleoclimatic study. Even in the case of stalagmites showing textures consistent with the preservation of paleoclimatic signals, it is advisable to obtain at least two coeval stalagmite records from the same cave or region to test their sensitivity to local versus climatic factors (i.e., a replication test; Dorale et al., 2002; Dorale \& Liu, 2009). In addition, the number of sampled stalamites may increase if they contain abundant detrital material, which complicates U-Th dating (Hellstrom, 2006), or specimens are affected by diagenetic alteration.

Therefore it is clear that most paleoclimatic studies based on stalagmites normally require sampling several specimens. Because the number of stalagmites in a cave is finite, sampling conflicts with cave conservation, especially for caves containing few speleothems. Therefore, the sampling strategy must be selective and trying to reach a compromise between the scientific goal and cave conservation issues. For instance, the shape and diameter of stalagmites may provide clues about their usefulness for paleoclimatice studies. This allows a screening, 
and commonly narrows the search down to those with constant diameters of about $11 \mathrm{~cm}$ or more (Dreybrodt \& Romanov, 2008; Dreybrodt \& Scholz, 2011).

To minimize the impact of stalagmite sampling, researchers have developed a variety of strategies. Frappier (2008) designed a screening strategy aimed to select paleoclimate-sensitive stalagmites. For instance, this author recommends the preferential sampling of already broken specimens due to natural causes (collapses), accidents, or modern or historical vandalism. This approach was followed by Dominguez-Villar et al. (2009) and Baldini et al. (2015), among others. Another strategy is coring the central part of stalagmites, either in the cave (Brook et al., 2006; Verheyden et al., 2006; Yang et al., 2007) or in the laboratory, in the latter case placing the drilled specimens back in their original location in the cave (Dorale et al., 1992). In any case, patching the drill holes is simple. Details of these methods are rarely published, with the notable exception of Spötl \& Mattey (2012).

Drilling stalagmites minimizes the visual impact of sampling. However it has some disadvantages. The best paleoclimatic records are those obtained from the axis of maximum extension (Dreybrodt \& Scholz, 2011). The growth axis of a stalagmite can change in time due to drip displacement. Therefore is almost impossible to anticipate if a given drill core will follow the growth axis in deeper parts of the stalagmite. Also, the small diameter of the cores only permits a limited view of the general structure of the stalagmite, especially when compared to longitudinal sections of the entire specimen. However, actually most coring is normally not done vertically (in order to obtain a complete profile) but horizontally near the base, simply to get a basal age of the specimen (Spötl \& Mattey, 2012).

In this paper we propose applying molding and casting laboratory techniques to create replicas of stalagmites sampled for paleoclimatic purposes, placing the replicas in the original cave locations so that the impact of sampling is severely reduced. For stalagmites that were actively growing when sampled, the deposition of new $\mathrm{CaCO}_{3}$ layers will likely make the replicas virtually undistinguishable from the natural specimens within a few years. The main objective of this article is to provide a detailed description of the methods. We report our experience in two caves (El Soplao and La Buenita, Cantabria, N Spain). Both caves are profusely decorated with speleothems and they were discovered during mining activities, which have resulted in considerable damage.

\section{PREVIOUS WORK}

To date, most replicas of stalagmites have been produced in prehistoric cave-art settings, where certain parts of caves with paintings have been reproduced entirely to preserve the fragile cave environments while allowing public display of the reproductions (Altamira Cave, Cantabria, Spain: Laheras et al., 2002 and Chauvet Cave, Ardèche, France: Pigeaud, 2014). Also, speleothem replicas have been produced to restore vandalized caves, such in Vatnshellir (Snæfellsnes, Iceland), where 37 replicas were generated to replace broken specimens (Stefánsson, 2010).

In the case of stalagmites sampled for scientific purposes, replicas are rarely considered and, when employed, technical details are typically not provided (Spötl \& Boch, 2012). Muñoz-García (2007) elaborated polyurethane-resin replicas of several stalagmites sampled for paleoclimatic purposes in Cobre Cave (N Spain). Vaks et al. (2013) replaced an active stalagmite by a ceramic replica in Okhotnichya Cave (Siberia, Russia), but no technical details about the replication process were provided. Truebe et al. (2011) elaborated a replica of a stalagmite sampled for a paleoclimatic study using a mixture of cement and crushed marble and temporarily placed a replica back in the cave (Kartchner Caverns, Arizona, USA) to determine whether the materials were suitable for the cave environment. Baeza \& Durán (2015) describe the replication of a peculiar speleothem from Las Maravillas Cave (Huelva, Spain). The original speleothem remained in the cave, and the replica was made for preserving its shape from possible future alteration. Finally, D. Tremaine and C. ScottSmith created reproductions of stalagmites used for paleolimate research from Hollow Ridge Cave (Florida, USA), using polyurethane-resin molds and a cement-glass mixture for casting (Florida State University, 2011).

\section{EL SOPLAO AND LA BUENITA CAVES}

El Soplao Cave is located in the Arnero Sierra (Cantabria, N Spain; Fig. 1). It contains $\sim 23 \mathrm{~km}$ of surveyed passages, developed in Aptian dolostone hosting Mississippi-Valley-type $\mathrm{Pb}-\mathrm{Zn}$ deposits. With no known natural entrances, El Soplao Cave was discovered during mining operations in 1908. E1 Soplao contains abundant calcite and aragonite speleothems (Gázquez et al., 2012; Rossi \& Lozano, 2016), including outstanding helictites and anthodites, which prompted the development of the westernmost section of El Soplao as a show-cave in 2005. U-series dating (Rossi et al., 2016) indicates that aragonite and calcite stalagmites and flowstones have grown intermittently in the caves at least for the last 1.5 Ma. El Soplao is particularly noteworthy for its unique ferromanganese stromatolites (Rossi et al., 2010), formed in water-

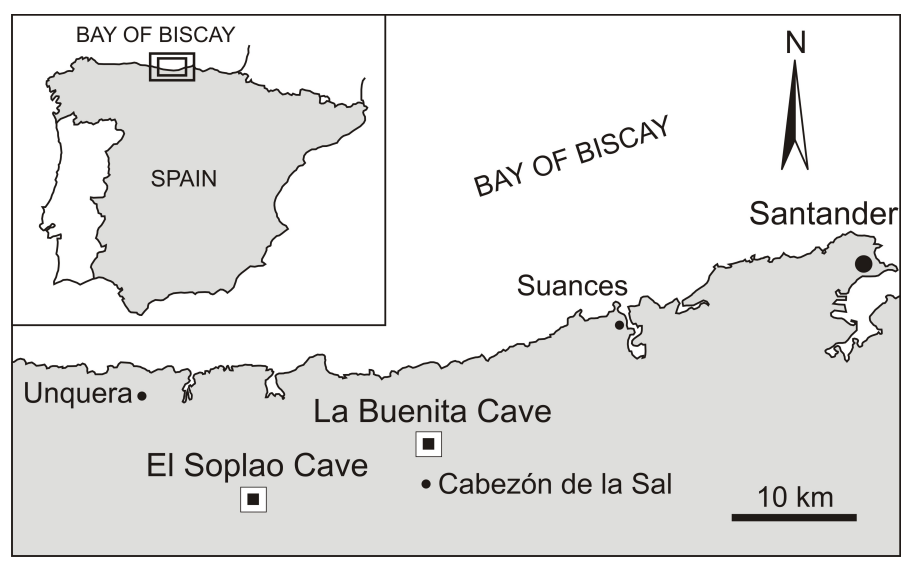

Fig. 1. Location of El Soplao and La Buenita caves. 
table canyons during the early Pleistocene as revealed by ${ }^{234} \mathrm{U}-{ }^{238} \mathrm{U}$ and paleomagnetic dating (Rossi et al., 2016). The stromatolites contain zaccagnaite-3R, a new polytype of the hydrotalcite group (Lozano et al., 2012) and unusually well preserved Mn-oxidizing microbes (Lozano \& Rossi, 2012). La Buenita Cave is located in the same region (Fig. 1), develop in the same Aptian dolostone formation as El Soplao was also discovered during mining operations.

\section{SAMPLED STALAGMITES}

Four stalagmites were sampled for paleoclimatic purposes in El Soplao (La Sirena passage) and one stalagmite in La Buenita (Table 1). La Buenita is not open to tourism, and la Sirena passage in El Soplao is located relatively far from the show-cave section. Three of the sampled stalagmites were located under active drips. The stalagmites consist of calcite passing laterally into flowstone. In the case of El Soplao, the speleothems grew on sand, gravel and clay with intercalated manganese speleo-stromatolites (Rossi et al., 2010). In both caves, the stalagmites were extracted using a portable diamond saw equipped with a $2-\mathrm{mm}-$ thick diamond blade). After performing typically one of two low-angle basal cuts, the stalagmite was removed with the aid of a hammer and a broad and flat chisel. This procedure minimizes the loss of material from the stalagmite base, so that placing back the replica is facilitated.

Tab. 1. Main relevant features of the replicated stalagmites.

\begin{tabular}{|l|c|c|c|c|c|}
\hline \multicolumn{1}{|c|}{ Stalagmite ID } & Drip activity & Height $\mathbf{( c m )}$ & Basal diameter $(\mathbf{c m})$ & Mold type & Emplacement date \\
\hline Soplao-1 & Inactive & 71 & 23 & 2-piece & June 2017 \\
\hline Soplao-2 & Inactive & 34 & 11 & 1-piece & March 2012 \\
\hline Soplao-3 & Active & 21 & 18 & 1-piece & March 2012 \\
\hline Soplao-4 & Active & 17 & 11 & 1-piece & June 2017 \\
\hline Buenita-1 & Active & 40 & 12 & 2-piece & June 2017 \\
\hline
\end{tabular}

\section{MOLDING AND CASTING}

Molding and casting procedures are slightly different depending on the stalagmite size, as detailed below. Also, resin pouring becomes more difficult with increasing mold size. For relatively small specimens (less than $\sim 40 \mathrm{~cm}$ tall), we use a single-piece silicone mold and two jackets, the resin being poured directly into the mold. For larger stalagmites $(\sim 40-70 \mathrm{~cm}$ tall), we use a two-piece mold and two jackets, the resin being introduced into the mold using a spatula and a brush. The precise molding and casting procedure for each case is described below.

\section{Case 1: Small stalagmites}

First, the stalagmite is placed vertically on a block of non-sulphure plasticine (Fig. 2A; Fig. 3A). Then, a layer of room-temperaturevulcanizing silicone (Down Corning 3481) is applied on the specimen with the aid of a brush (Fig. 2A; Fig. 3B). During this step, silicone viscosity exerts a major control on the quality of the replica. If the silicone is too fluid, it could penetrate into pores of the specimen, complicating demoulding. If the silicone is too viscous, bubbles may form, decreasing the quality of the replica. Optimal viscosity levels are achieved by adding $7 \%$ wt. of curing Agent 3481-F.

After applying a second layer of thixotropic silicone (Fig. 3C) and immediately before curing, a nylon network is fixed to the silicone to increase its stability (Fig. 2B; Fig. 3D). Then, a third, 1-cm thick, blue-dyed thixotropic silicone layer is applied. When all silicone layers are cured, the plasticine basal stand is removed (Fig. 3E).

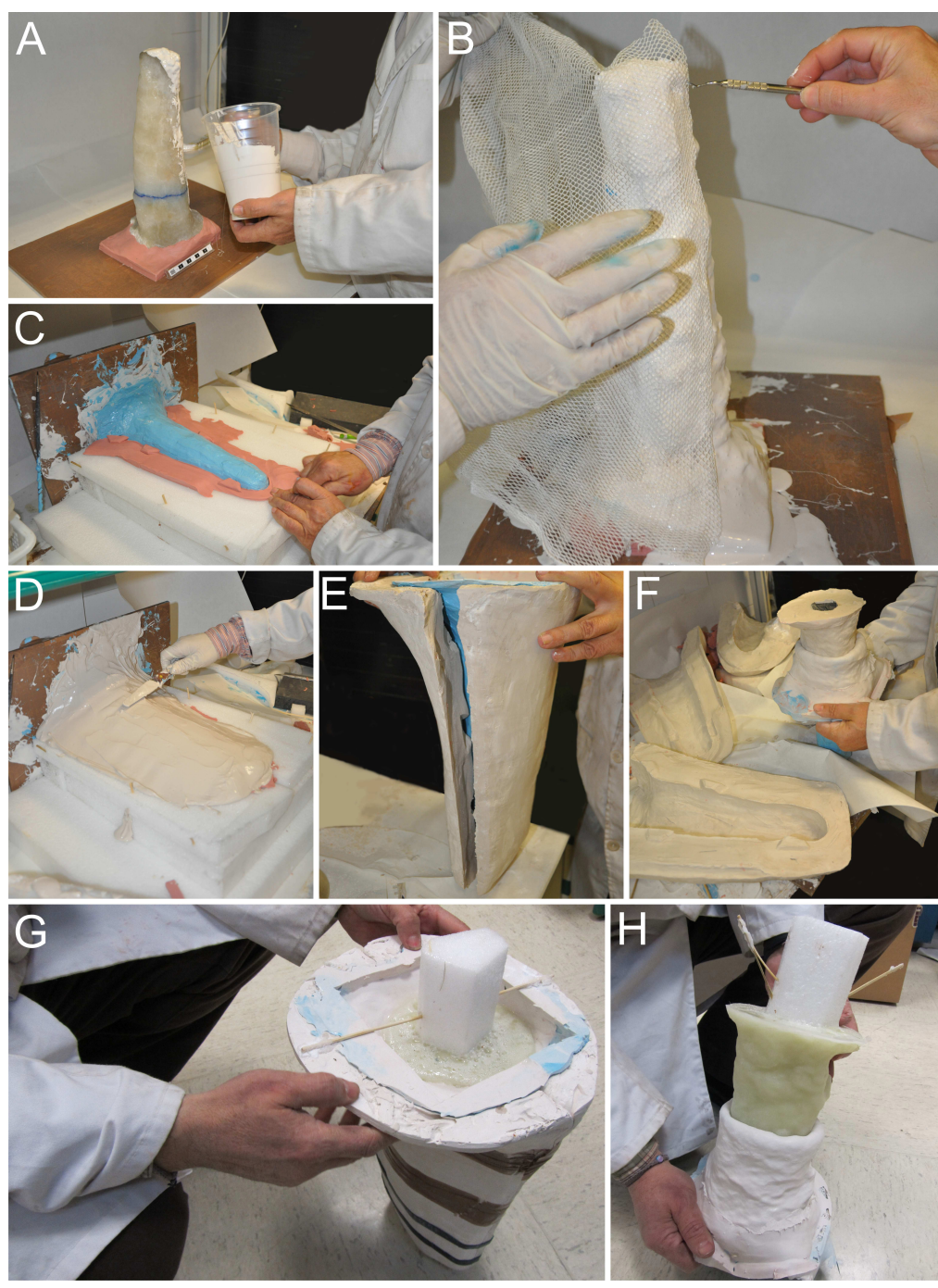

Fig. 2. Molding and casting procedures for the Soplao-2 stalagmite $(34 \mathrm{~cm}$ tall). A) Silicone is applied on the specimen using a brush; B) Nylon network fixing; C) Adaptation of the assembly to the polyethylene sheet; D) Manufacture of the plaster jacket; E) Opening of the jackets for the extraction of the silicone mold; F) Extraction of the dental-plaster master replica; G) Inserting a thick polyethylene rod into the axis of the mold with the aid of a thin wooden stick; $\mathrm{H}$ ) Extraction of the resin replica with the polyethylene core. 
Once cured, the silicone mold can be easily deformed. Therefore, pouring resin or plaster into the mold will likely result in deformed replicas. To avoid this, two rigid jackets plaster (low hardness, type II; Alamo 70) are prepared to be fixed to the mold. To prepare the first jacket, the silicone-covered stalagmite is placed horizontally over a thick section of polyethylene foam, which is previously prepared to fit the specimen by removing material from its central part (Fig. 3F). Plasticine is used to improve the fit between the silicone and the polyethylene foam (Fig. 2C). The jacket is fixed to the silicone mold by using swallowtail keys made of plasticine. To improve stability, an additional piece of polyethylene foam is adjusted to the base of the stalagmite (Fig. 3F). Finally, to prevent plaster from penetrating the surface of the silicone mold, the latter is wrapped in polyethylene film. Following hardening of the first plaster jacket, both the sillicone-covered specimen and the jacket are flipped together (Fig. $3 \mathrm{H}$ ), so that a second plaster jacket can be prepared, similar to the first one (Fig. 3I).

A first casting is performed using high-hardness type-IV dental plaster (a 50\% mixture of Hebodur and Arquero). The resulting master replica is preserved, so that a new mold can be prepared in case the first mold is damaged. A second casting provides the replica to be placed in the cave. For this casting, we used epoxy resin (Fetadit 55/63), charged with silica powder. To reduce replica weight and cost prior to pouring the resin we fixed a thick polyethylene rod into the axis of the mold with the aid of a thin wooden stick (Fig. 2G; Fig. 3K-L). This procedure also prevents unwanted increases in temperature during resin curing.

To obtain a color as close as possible to that in the surface of the original specimen, we first perform several tests by combining dyes, obtaining several

Case I: small stalagmites $(<40 \mathrm{~cm})$

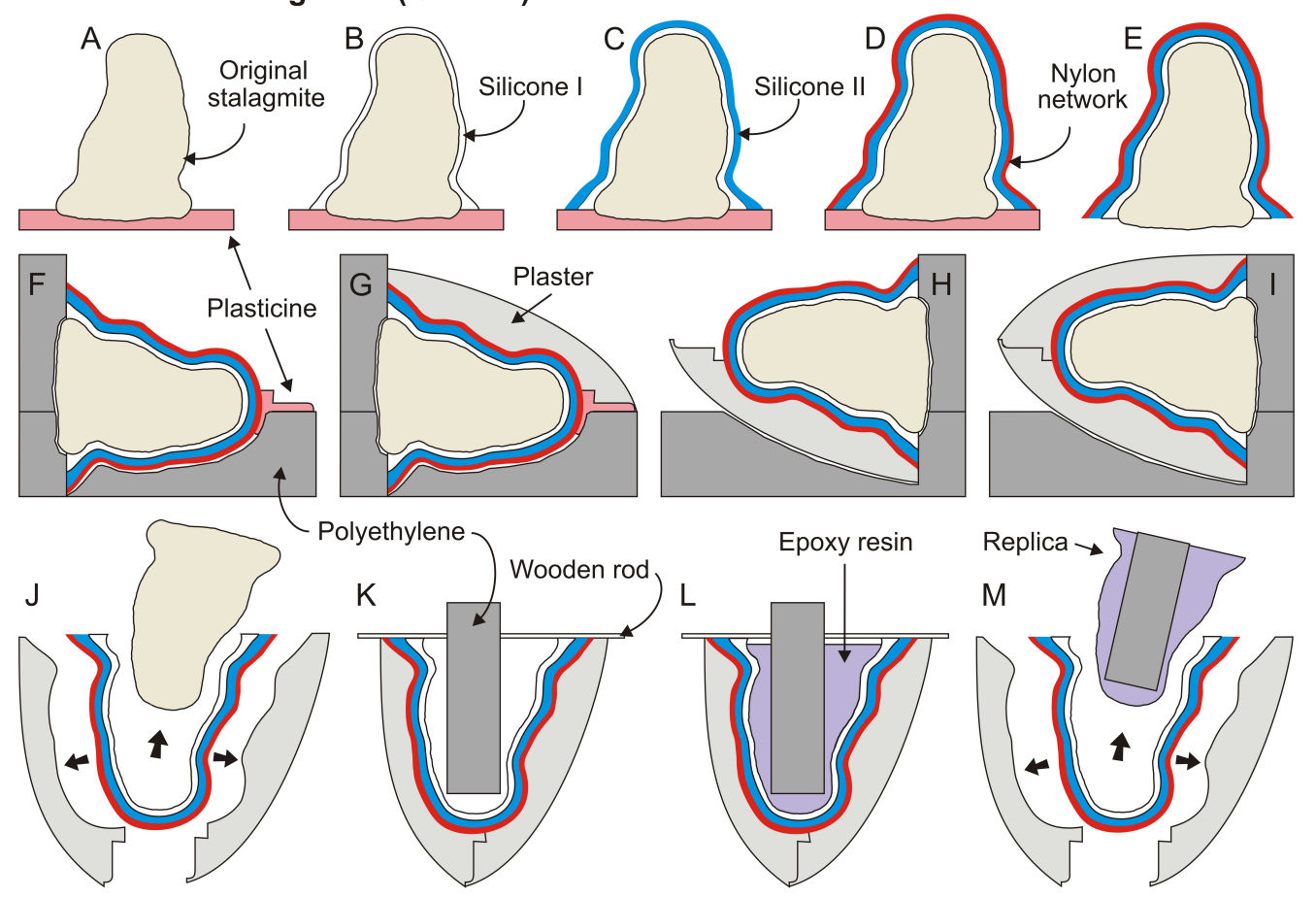

Case II: large stalagmites ( $\geq 40 \mathrm{~cm})$

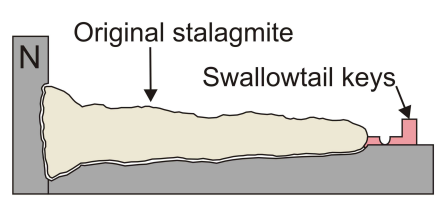

Q

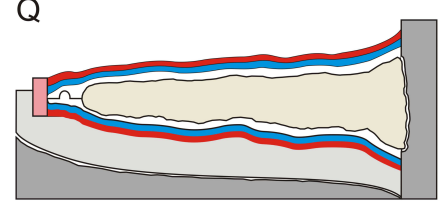

$\mathrm{S}$

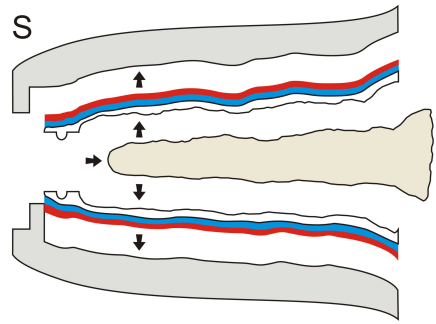

Fig. 3. Molding and casting scheme for stalagmites. See description in text.

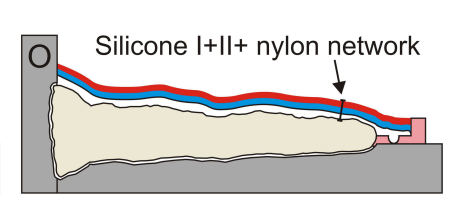

$\mathrm{R}$

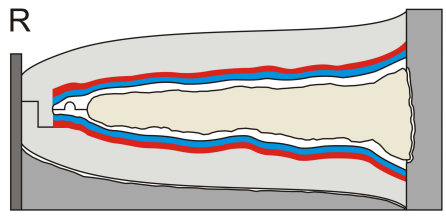

T Epoxy resin + cellulose

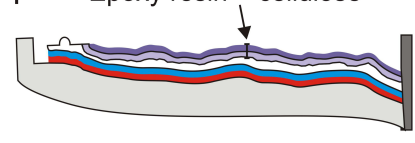

U

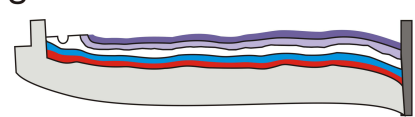

Polyethylene barrier

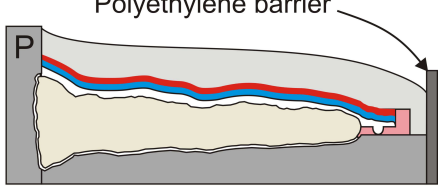

$\mathrm{V}$

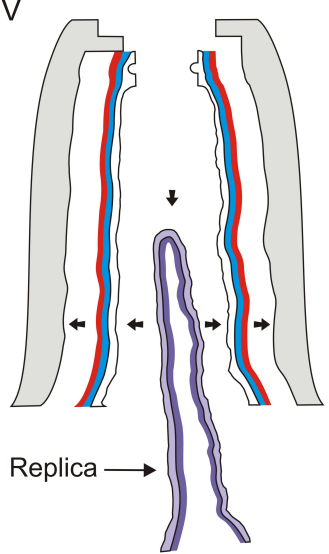


fragments of colored resin. To achieve best results, we do not apply the chosen dyes on the finished replica, but on the internal part of the silicone mold, before introducing the epoxy resin of the casting. Thus the dye penetrates the resin, permanently coloring the selected sectors. To make sure that the resulting color is right, we previously did a series of color tests using a silicone mold divided into several hollow spaces (5 $55 \mathrm{~cm}$ section and $1 \mathrm{~cm}$ deep). We impregnate the bottom of each space with the selected mixture of dyes and introduce the epoxy resin. After curing, we check the surface color obtained. The application of the pigment to the silicone can be done in dry or wet conditions. However, we recommend the wet application because it produces a glossy aspect in the finished replica very similar to most of the original specimens.

\section{Case 2: Large stalagmites}

For larger stalagmites $(\sim 40-70 \mathrm{~cm}$ tall) inserting polyethylene rods in the mold axis before resin pouring is more delicate, as it becomes more difficult to prevent the rods from touching the mold walls. Therefore, in these cases it is advisable to elaborate a two-piece instead of a singlepiece mold so that it is easier to safely insert polyethylene rods in the mold and the volume of resin used is minimized. Also, as the silicone molds become larger they are more prone to break during casting.

First, a cavity is carved into a thick piece of polyethylene foam to fit one longitudinal half of the stalagmite. A layer of plasticine is then applied on the surface of the polyethylene foam, and a groove is carved in the plasticine near the edges of the stalagmite. This groove is the link between the two silicone molds and prevents possible spills during casting. Plasticine swallowtail keys are prepared to obtain a good fit between the future jacket and the specimen (Fig. 4A; Fig. 3N) and to improve stability when both are placed in a vertical position. The exposed half of the specimen is covered by three layers of silicone-bearing nylon network, similar to case 1 (Fig. 4B; Fig. 3O). A barrier of paper-covered polyethylene foam sheets is then glued to the base of the polyethylene foam. Finally, the first jacket is obtained by covering the silicone-covered stalagmite with low-hardness plaster (Fig. 4C; Fig. 3P).

Following hardening of the first plaster jacket, both the sillicone-covered specimen and the jacket are flipped together, removing the basal piece of polyethylene foam in order to expose the other half of the stalagmite. Again, plasticine swallowtail keys are prepared (Fig. 4D). Before covering the corresponding half of the stalagmite with silicone, a release agent (black soap) must be applied to the first mold to prevent the molds from sticking together. After applying the silicone layers (Fig. 3Q) and wrapping with polyethylene film, a barrier of polyethylene foam is spread around the set. This prevents plaster spills during the elaboration of the second jacket (Fig. 4E-F; Fig. 3R). Once the plaster of the second jacket is hard, the polyethylene foam barriers are removed (Fig. 4G) and the set is opened (Fig. 4H) to release the stalagmite (Fig. 4I; Fig. 3S).

Similar to case 1 , a first casting is performed using type-IV dental plaster to obtain a master replica, and the replica is obtained by means of a second casting using dyed epoxy resin (Fetadit 55/63). This is done by applying a $\sim 0.5 \mathrm{~mm}$ thick resin layer to the inner parts of each mold, with the aid of a brush (Fig. 3T-U). Then, $\sim 6 \%$ cellulose is added to the epoxy resin, which is applied over the epoxy layer using a spatula (layer thickness: 1-2 cm). The purpose of adding cellulose is to regulate the transparency of the epoxy resin. Then, both molds and their respective jackets are assembled together. After resin curing, a light-weight and hollow replica is obtained, ready to be placed into the cave (Fig. 3V). The procedure to obtain the final color of the replicas is similar to that described for case 1 .
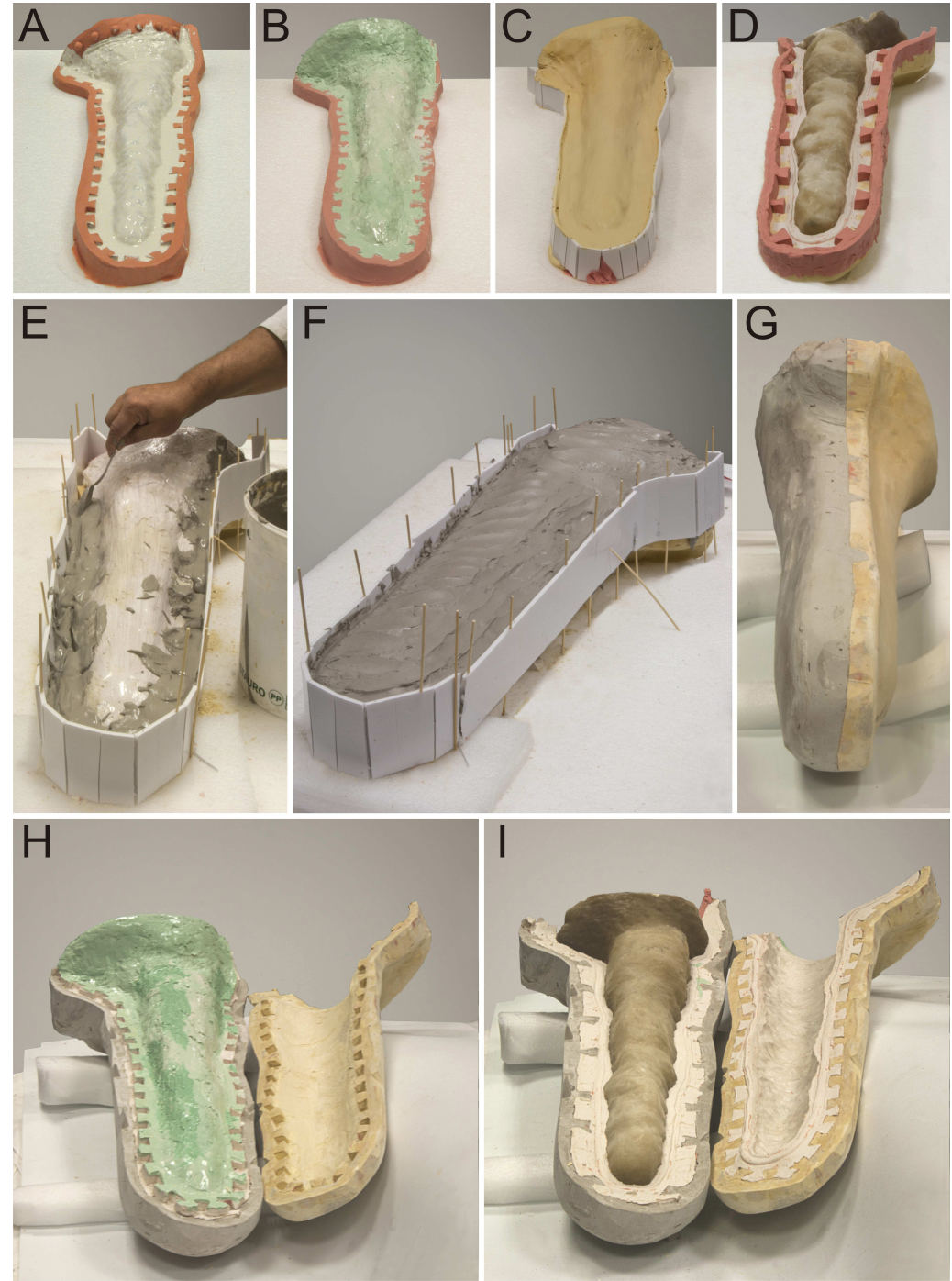

Fig. 4. Molding and casting procedures for the Soplao- 1 stalagmite $(71 \mathrm{~cm}$ tall). A) Original stalagmite covered with the first brush of silicone and placed on a thick polyethylene plate; B) Application of the second layer of silicone and polyethylene film; C) Installation of polyethylene barriers and application of plaster to manufacture the first jacket; D) Manufacture of new plasticine swallowtail keys for the second mold production; E-F) Installation of new polyethylene barriers for the application of the plaster of the second jacket; $G$ ) Set of molds and carcasses with the original stalagmite inside; $\mathrm{H}-\mathrm{I}$ ) Extraction of the original stalagmite. 


\section{ANCHORING OF STALAGMITE REPLICAS TO THE ORIGINAL SUBSTRATES IN THE CAVES}

After cleaning and drying the substrate of the stalagmite, the replica is placed to match the original orientation using images taken before extracting the specimens and the impact location of the drops falling from the corresponding stalactite. To fix the replica to the cave floor, we used high hardness plaster (Arquero; type IV) coated with epoxy resin. We use an umbrella to avoid the impact of drops during plaster and resin hardening. In the case of relatively flat substrates, the insertion of the replicas is relatively easy (Fig. 5A-D) and simply involves dying the plaster to match the appropriate color.

However, the insertion on inclined substrates, such as for stalagmite Soplao-1, is more difficult. This stalagmite passed laterally into a thin flowstone overlying unconsolidated detrital sediments (Fig. 5E), which was partially broken during stalagmite extraction. Therefore, a layer of dyed plaster, resembling the original flowstone, was applied during the insertion of the replica (Fig. 5F).

\section{LONG-TERM STABILITY OF THE REPLICAS}

The long-term stability of the materials used in the replicas is of great importance because they can deteriorate easily under cave conditions (Werker, 2006ab; Werker \& Hildreth-Werker, 2006). The epoxy resin we have used for both casting and covering the insertion plaster is manufactured locally, so it does not appear in the lists published by Werker (2006a) or Werker \& Hildreth-Werker (2006). This resin is of relatively good quality and we have used it for more than two decades in diverse restoration projects with excellent results and durability. However, its longterm stability inside the caves has not been described so far. After almost six years in the cave, replicas Soplao-2 and Soplao-3 (emplaced in March, 2012) have not experienced any obvious signs of alteration, suggesting that the used epoxy is rather stable in the cave environment.

Regarding the plaster used for anchoring the replicas to the substrate, we initially tested its stability in the laboratory by submerging a $\sim 125-\mathrm{cm}^{3}$ piece in deionized water for one year in an isolated environment. After this time the conductivity of the water barely increased, implying no significant dissolution of the plaster. Therefore this material seemed adequate to fix the replicas to the substrate. However, tests at the El Soplao Cave showed that the plaster partially disintegrated rapidly (in a few months) when dripwater hit it directly, but much slower when it was at the base of the stalagmite. We solved the problem by coating the base of the stalagmite with a layer of epoxy resin, which effectively waterproofed the plaster. This epoxy resin is the same used in the casting of the replicas.

In the replicas, we have only used inorganic dyes that should be relatively inert in the cave environment: iron oxi-hydroxides (light yellow to dark brown), titanium

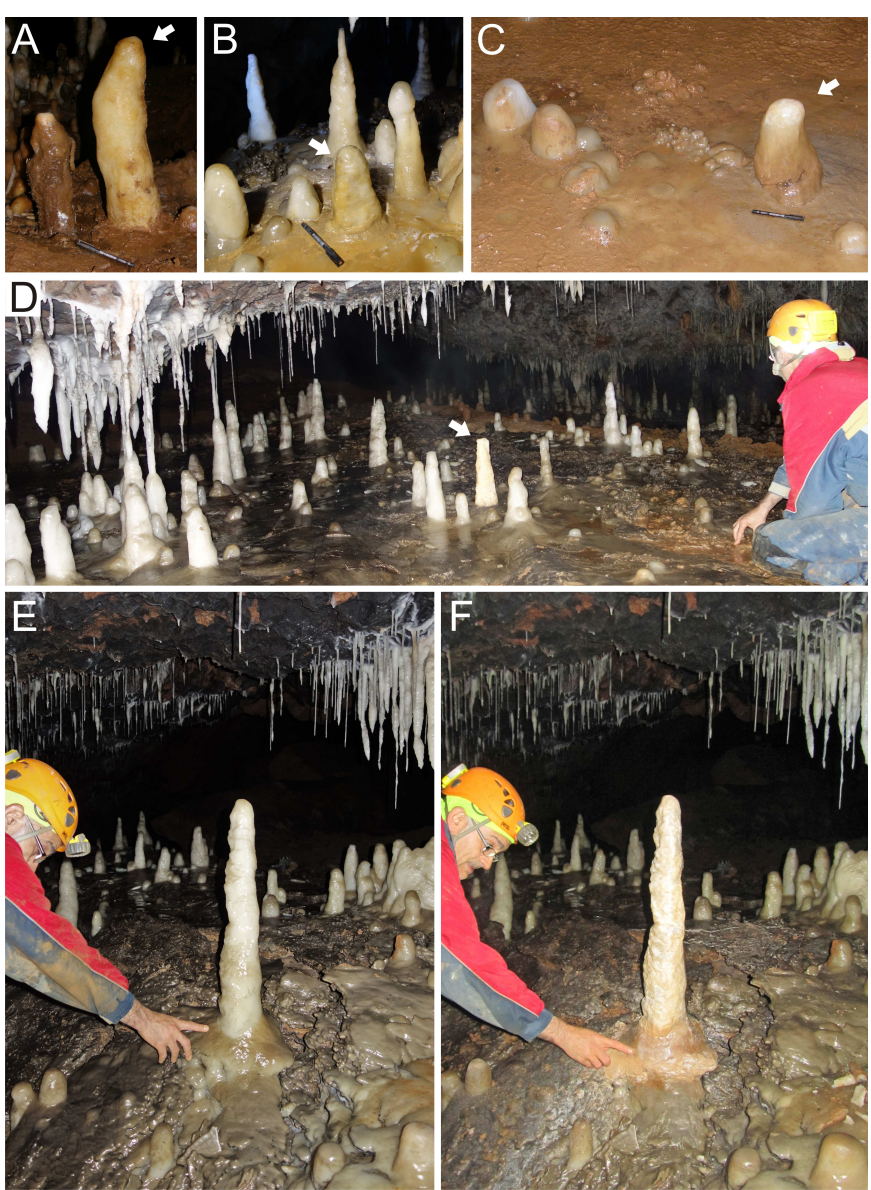

Fig. 5. Replicas installed in La Buenita Cave (A) and in La Sirena Passage (EI Soplao Cave) (B, C, D, E, F). A) Replica of the Buenita-1 stalagmite; B-C-D) Replicas of Soplao-4, Soplao-3 and Soplao-2 stalagmite, respectively; E) Soplao-1 stalagmite before sampling; F) Replica of Soplao-1 stalagmite placed in its original location.

oxide (white) and graphite (black). Furthermore, these dyes are not exotic in the caves we are dealing with: in El Soplao Cave, titanium and iron oxides are abundant in detrital sediments, speleo-stromatolites, and cave walls (Rossi et al., 2010; Lozano et al., 2012), and coal fragments are locally present in the host rock (García et al., 2007).

Given the significant anthropogenic influence in the caves associated with mining during the $20^{\text {th }}$ century (García et al., 2007), we did not sterilized the replicas before placing them in the caves. Even though, so far we have not observed any perceptible microbial disturbances on the surfaces of the replicas that have remained in the cave for $\sim 6$ years.

For the replicas of stalagmites that were actively growing when sampled (3), it is reasonable to assume that the deposition of new $\mathrm{CaCO}_{3}$ layers will further stabilize the replicas in the cave environment. Two of these replicas (Soplao-4 and Buenita-1) were placed in the caves in June 2017, so significant layers of recent calcite are probably not developed yet on their surfaces. The remaining "active" replica was placed in 2012, but recent calcite precipitation is prevented by the presence of a drip-counting device on its surface. Therefore, we have no information yet on how modern calcite is adhering to and growing over the replicas. However, in drip sites of El Soplao Cave characterized by relatively high $\mathrm{CaCO}_{3}$ supersaturations (saturation index for calcite around 0.8-1.2: Rossi \& Lozano, 2016), obvious crusts of recent calcite are covering 
stalagmite surfaces that were restored with epoxy putty after localized sampling (Rossi \& Lozano, 2016). Such crusts have developed in less than two years, suggesting that the epoxy replicas located under active drips will be eventually covered by calcite too.

\section{CONCLUSIONS}

Elaborating replicas of stalagmites sampled for paleoclimatic studies is an effective means to reconcile scientific research and cave conservation. Once in place, the stalagmite replicas are almost indistinguishable from the natural specimens. In the case of originally active stalagmites, the impact of sampling will be likely erased in a few years, depending on the rate of calcite deposition.

The molding and casting methods vary depending on stalagmite size. For relatively small specimens (less than $\sim 35 \mathrm{~cm}$ tall), we use a single-piece mold and two jackets. For larger stalagmites $(\sim 40-70 \mathrm{~cm}$ tall), we use a two-piece mold and two jackets.

To reduce replica weight and costs, and to prevent unwanted temperature increases, for relatively small specimens we introduce polyethylene rods into mold axes during casting. For larger specimens, we use techniques to produce hollow casts.

We use extra-hard plaster coated with epoxy resin to fix the replicas to their original substrates. Both the epoxy resin and plaster are carefully dyed to match the original surface texture and color of the sampled stalagmites.

The epoxy used to elaborate and emplace the replicas, as well as the dyes used, are apparently stable in the cave environment, at least for periods of at least six years.

\section{ACKNOWLEDGEMENTS}

Financial support was provided by grant ICTSoplao- 53.5.00.12.00 (IGME - Provincial Government of Cantabria - Turismo del Nansa). We specially thank A. Argumosa, manager of El Soplao S.L., for greatly supporting and facilitating our research in the cave. The highly constructive comments by reviewers C. Spötl, S. Truebe, and by editor B.P. Onac, greatly improved the manuscript.

\section{REFERENCES}

Baeza E. \& Durán J.J., 2015 - Proceso de realización de moldes y réplicas de un espeleotema singular: el caso de "La Palmatoria", Gruta de las Maravillas, Aracena (Huelva, España). Pesquisas em Turismo e Paisagens Cársticas, 8 (1): 65-73.

Baldini L.M., McDermott F., Baldini J.U.L., Arias P., Cueto M., Fairchild I.J., Hoffmann D.L., Mattey D.P., Müller W., Nita D.C., Ontañón R., García-Moncó C. \& Richards D.A., 2015 - Regional temperature, atmospheric circulation, and sea-ice variability within the Younger Dryas Event constrained using a speleothem from northern Iberia. Earth and Planetary Science Letters, 419: 101-110. https://doi.org/10.1016/j.epsl.2015.03.015

Brook G.A., Ellwood B.B., Railsback L.B. \& Cowart J.B., 2006 - A 164 ka record of environmental change in the
American Southwest from a Carlsbad Cavern speleothem. Palaeogeography Palaeoclimatology Palaeoecology, 237: 483-507.

https://doi.org/10.1016/j.palaeo.2006.01.001

Dominguez-Villar D., Fairchild I.J., Baker A., Wang X., Edwards R.L. \& Cheng H., 2009 - Oxygen isotope precipitation anomaly in the North Atlantic region during the 8.2 ka event. Geology, 37: 1095-1098.

https://doi.org/10.1130/G30393A.1

Dorale J.A., González L.A., Reagan M.K., Pickett D.A., Murrell M.T. \& Baker R.G., 1992 - A high-resolution record of Holocene climate change in speleothem calcite from Cold Water Cave, northeast Iowa. Science, 258: 1626-1630.

https://doi.org/10.1126/science.258.5088.1626

Dorale J.E., Edwards R.L. \& Onac B.P., 2002 - Stable isotopes as environmental indicators in speleothems. In: Yuan D. \& Zhang C. (Eds.), Karst processes and the carbon cycle. Final Report of IGCP 379, Geological Publishing House, Beijing, p. 107-120.

Dorale J.A. \& Liu Z., 2009 - Limitations of Hendy test criteria in judging the paleoclimatic suitability of speleothems and the need for replication. Journal of Cave and Karst Studies, 71: 73-80.

Dreybrodt W. \& Romanov D., 2008 - Regular stalagmites: the theory behind their shape. Acta Carsologica, 37: $175-184$.

Dreybrodt W. \& Scholz D., 2011 - Climatic dependence of stable carbon and oxygen isotope signals recorded in speleothems: From soil water to speleothem calcite. Geochimica et Cosmochimica Acta, 75: 734-752. https://doi.org/10.1016/j.gca.2010.11.002

Fairchild I.J. \& Baker A., 2012 - Speleothem science: from process to past environments. Wiley-Blackwell, Chichester, $450 \mathrm{p}$. https://doi.org/10.1002/9781444361094

Florida State University, 2011 - Researcher finds key to ancient weather patterns in Florida's caves. https:// phys.org/news/2011-12-key-ancient-weatherpatterns-florida.html. Date of access: 02/20/2018.

Fleitmann D. \& Spötl C., 2008 - Editorial: Advances in speleothem research. PAGES News, 16 (3): 2. https://doi.org/10.22498/pages.16.3.2

Frappier A.B., 2008 - A stepwise screening system to select storm-sensitive stalagmites: Taking a targeted approach to speleothem sampling methodology. Quaternary International, 187: 25-39. https://doi.org/10.1016/j.quaint.2007.09.042

García G., Palero F.J., Rabadán J. \& Medrosa M., 2007 Minas de La Florida. Bocamina, 20: 14-79.

Gázquez F., Calaforra J.M., Rull F., Forti P. \& GarcíaCasco A., 2012 - Organic matter of fossil origin in the amberine speleothems from El Soplao Cave (Cantabria, Northern Spain). International Journal of Speleology, 41: 113-123.

https://doi.org/10.5038/1827-806X.41.1.12

Hellstrom J., 2006 - U-Th dating of speleothems with high initial ${ }^{230}$ Th using stratigraphical constraint. Quaternary Geochronology, 1: 289-295.

https://doi.org/10.1016/j.quageo.2007.01.004

Lasheras J.A., de las Heras C., Montes P., Rasines del Río P., Fatás P., 2002 - La Altamira del siglo XXI: el nuevo museo y centro de investigación de Altamira. Patrimonio Histórico de Castilla y León, 8: 23-34.

Lozano R.P. \& Rossi C., 2012 - Exceptional preservation of Mn-oxidizing microbes in cave stromatolites (El Soplao, Spain). Sedimentary Geology, 255-256: 42-55. https://doi.org/10.1016/j.sedgeo.2012.02.003 
Lozano R.P., Rossi C., La Iglesia A. \& Matesanz E., 2012 - Zaccagnaite-3R, a new Zn-Al hydrotalcite polytype from El Soplao cave (Cantabria, Spain). American Mineralogist, 97: 513-523.

https://doi.org/10.2138/am.2012.3908

Muñoz-García B., 2007 - Los espeleotemas holocenos y pleistocenos de la cueva del cobre (Sierra de Peña Labra, Palencia) como indicadores de variedad climática. Unpublished Doctoral Thesis, Universidad Complutense de Madrid 308 p.

Pigeaud R., 2014 - Chauvet II copie d'un chef d'œuvre. Dossiers d'Archéologie, 361: 60-61.

Rossi C. \& Lozano R.P., 2016 - Hydrochemical controls on aragonite versus calcite precipitation in cave dripwaters. Geochimica et Cosmochimica Acta, 192: 70-96. https://doi.org/10.1016/j.gca.2016.07.021

Rossi C., Lozano R.P., Isanta N. \& Hellstrom J., 2010 Manganese stromatolites in caves: El Soplao (Cantabria, Spain). Geology, 38 (12): 1119-1122. https://doi.org/10.1130/G31283.1

Rossi C., Villalaín J.J., Lozano R.P. \& Hellstrom J., 2016 Paleo-watertable definition using cave ferromanganese stromatolites and associated cave-wall notches (Sierra de Arnero, Spain). Geomorphology, 261: 57-75. https://doi.org/10.1016/j.geomorph.2016.02.023

Spötl C. \& Boch R., 2012 - Uranium series dating of speleothems. In: White W.B. \& Culver D.C. (Eds.), Encyclopedia of caves. Elsevier, p. 838-844. https://doi.org/10.1016/B978-0-12-383832-2.00121-3

Spötl C. \& Mattey D., 2012 - Scientific drilling of speleothems, a technical note. International Journal of Speleology, 41 (1): 29-34. https://doi.org/10.5038/1827-806X.41.1.4

Springer G.S., 2012 - The ethics of collecting stalagmites in support of science. National Speleological Society News, June 2012, p. 12-14.

Stefánsson A.B., 2010 - The Vatnshellir Project, a first for Iceland. In: Middleton G.J. (Ed.), Proceedings of the International Symposium on Vulcanospeleology. Queensland, Australia, p. 115-121.
Truebe S., 2013 - A preliminary assessment of speleothem sampling methods for paleoclimate research. In: Land L. \& Joop M. (Eds.), Proceedings of the National Cave and Karst Management Symposium. Carlsbad, New Mexico, p. 47-50.

Truebe S., Cole J.E., Lee M. \& Barnett H.R., 2011 Reconciling speleothem sampling for paleoclimate research with cave conservation. In: Stratford V. (Ed.), Proceedings of the National Cave and Karst Management Symposium. Midway, Utah, p. 149-153.

Vaks A., Gutareva O.S., Breitenbach S.F.M., Avirmed E., Mason A.J., Thomas A.L., Osinzev A.V., Kononov A.M. \& Henderson G.M., 2013 - Speleothems reveal 500 kyr history of Siberian permafrost. Science, 340: 183-186. https://doi.org/10.1126/science.1228729

Verheyden S., Baele J.M., Keppens E., Genty D., Cattani O., Cheng H., Edwards L., Zhang H., van Strijdonck M. \& Quinif Y., 2006 - The Proserpine stalagmite (HanSur-Lesse Cave, Belgium): preliminary environmental interpretation of the last 1000 years as recorded in a layered speleothem. Geologica Belgica, 9: 245-256.

Werker J.C., 2006a - Materials considerations for cave installations. In: Werker V.H. \& Werker J.C. (Eds.), Cave conservation and restoration. National Speleological Society, p. 167-174.

Werker J.C., 2006b - Stalagmite repair. In: Werker V.H. \& Werker J.C. (Eds.), Cave conservation and restoration. National Speleological Society, p. 461-463.

Werker J.C. \& Hildreth-Werker V., 2006 - Speleothem repair materials. In: Werker V.H. \& Werker J.C. (Eds.), Cave conservation and restoration. National Speleological Society, p. 445-450.

Yang X., Zhang P., Cheng F., Huh C., Li H., Cheng H., Johnson K.R., Liu J. \& An C., 2007 - Modern stalagmite oxygen isotopic composition and its implications of climatic change from a high-elevation cave in the eastern Qinghai-Tibet Plateau over the past 50 years. Chinese Science Bulletin, 52: 1238-1247. https://doi.org/10.1007/s11434-007-0166-4 